\title{
Enhancing English Learners' Willingness to Communicate through Debate and Philosophy Inquiry Discussion
}

\author{
Mardziah Shamsudin $^{1,2}$, Moomala Othman ${ }^{1}$, Maryam Jahedi ${ }^{1} \&$ Dalia Aralas ${ }^{3}$ \\ ${ }^{1}$ Department of Language and Humanities Education, Faculty of Educational Studies, Universiti Putra Malaysia, \\ 43400, Serdang, Selangor, Malaysia \\ ${ }^{2}$ Language Center, National Defence University of Malaysia, Malaysia \\ ${ }^{3}$ Department of Foundations of Education, Faculty of Educational Studies, Universiti Putra Malaysia, 43400, \\ Serdang, Selangor, Malaysia \\ Correspondence: Moomala Othman, Department of Language and Humanities Education, Faculty of Educational \\ Studies, Universiti Putra Malaysia, 43400, Serdang, Selangor, Malaysia. E-mail: moomalaothman@yahoo.com
}

Received: June 17, 2017 Accepted: July 19, 2017 Online Published: July 21, 2017

doi: 10.5539/elt.v10n8p145 URL: http://doi.org/10.5539/elt.v10n8p145

\begin{abstract}
The present study investigated the impact of two instructional methods, Debate and Philosophy Inquiry (PI), in enhancing Willingness to Communicate (WTC) among two groups of English as a Second Language (ESL) learners who were randomly selected. In each group there were sixteen participants. The researchers used independent samples t-test and paired samples t-test to analyze the collected data. The data analysis using paired samples t-test showed that both methods of instruction have a significant effect on learners' WTC. However, the learners' WTC increased more in Debate group comparing to the Philosophy Inquiry classroom discussion group. The results indicate that Debate is more effective than Philosophy Inquiry classroom discussion in enhancing ESL learners' WTC.
\end{abstract}

Keywords: debate, second language learners, philosophy inquiry classroom discussion, willingness to communicate

\section{Introduction}

Willingness to Communicate (WTC) is "a personality-based, trait-like predisposition which is relatively consistent across a variety of communication contexts and types of receivers" (McCroskey \& Baer, 1985, p. 6). Moreover, it is viewed "as a readiness to speak in the L2 at a particular time with a specific person, and as such, is the final psychological step to the initiation of L2 communication" (MacIntyre \& Doucette, 2010, p. 162). In recent years researchers have attempted to examine learners studying English as a second language (ESL) or English as a foreign language (EFL) to find their Willingness to Communicate; however, previous studies have not addressed the influence of these methods of instruction i.e., Debate and Philosophy Inquiry (PI) discussion, on students' WTC. Both these approaches are known to be student centered and to promote learners' communicative skills. Therefore, this study attempted to examine the effectiveness of these two student-centered methods in promoting TESL undergraduates' WTC in classrooms. Therefore, this paper was an attempt to answer the following research questions:

1) Do PI classroom discussion and Debate instructional methods make any differences on ESL learners' WTC scores?

2) Is there any significant difference between mean scores of Debate and PI classroom discussion groups?

3) Which method of instruction promotes Self-Communicative Competence (CA) more: PI discussion or Debate?

4) Which method of instruction increases Communicative Apprehension (CA) more: PI discussion or Debate?

\subsection{Willingness to Communicate (WTC)}

Willingness to Communicate (WTC) refers to a person's motivation to use the target language to communicate in a situation (Dörnyei, 2003, 2005). Speaking is important in language development and acquisition. As stated by Swain (1985), a quality language output between a learner and a teacher has a direct impact on the achievement 
of language progress. Hence, the assertion is made by MacIntyre et al. (2003) who believe that the fundamental goal of language instruction is to trigger this psychologically driven process in a learner. According to Skehan $(1989$, p. 48), once initiated, the learner will "talk the language" and in the process he will learn or acquire the language. There are many factors that affects one's Willingness to Communicate, which basically are people and/or situation-specific qualities such as aptitude, motivation, interlocutors (friends or acquaintances) and context. Researchers also distinguish between WTC inside the classroom, when students are requested to answer questions, and WTC outside the classroom, when interacting with friends or acquaintances. What a teacher choose to do in the classroom context will also affect the students' WTC.

Willingness to Communicate is mostly dependent on two elements i.e., Communication Apprehension (CA) and Self-Communicative Competence (CC). Communication Apprehension refers to the anxiety that the learners experience in communicating. This is most prominent in adult learners as speaking is a public activity that indirectly affects one's self-esteem. The moment individuals attempt to deliver an idea, it is inevitable for them to become conscious of others' perception on their own ability and it is this anxiety that impedes their attempts to speak up (MacIntyre \& Gardner, 1994). McCroskey and Richmond (1987) asserted that, those who experience high communicative apprehension will most likely withdraw or avoid communication. Another important element of WTC is Communicative Competence. This is defined as the feeling of confidence one has to communicate effectively in a particular situation (MacIntyre et al., 1998). The sense of efficacy arises due to previous successful communication encounters and having the knowledge and skills to carry out the task again (Weaver, 2010). Hence, this feeling to successfully carry out a communicative task correlates with the feeling of lack of anxiety to perform the task.

McCroskey and Richmond (1990) argued that people who perceive themselves as poor communicators are less willing to communicate. Baker and MacIntyre et al. (2001) concluded that reduced anxiety and increased perceived competence means that students would be more willing to communicate. However, they pointed out that anxiety is more crucial among advanced learners while for less experienced students, perceived competence is the key factor.

\subsection{Debate}

Debate is an ancient practice which is 2,400 years old (Garrett et al., 1996). Protagoras, "the father of Debate", introduced it as a teaching method in Ancient Greece (Darby, 2007) and later in the twelfth century, Muslims scholars in colleges used this pedagogy to teach Islamic Jurisprudence (Makdisi, 1981). Debate is an activity which involves discussion on a matter with people whose opinions are different and/or contradictory. It requires participants to be open-minded to be able to decide the best solution when voting their opinion after listening and arguing opinions. Being open-minded is one of the predispositions of being a critical thinker. Another attribute of Debate is boldness in expressing ones' opinion. Perhaps, this is the reason why many claim that Debate is related to democracy and freedom of speech (Ericson et al., 2003).

Today, in the United States, Debate is a popular teaching tool in schools and at its tertiary levels where it is used in various disciplines (Jugdev et al., 2004). Research in Debate classroom at university level reveals that Debate promotes critical thinking (Hall, 2011) and offers many advantages all in one go. Among them are: clarifying ideas and presenting arguments (Bellon, 2000), better understanding of content knowledge (Vo \& Morris, 2006), improving personal skills and critical understanding (Moon, 2005; Kennedy, 2007), improving persuasive public speaking skills and improving listening skills (Oros, 2007) and bolstering teamwork (Gervey, 2009).

Despite many benefits of Debate as a teaching method, it is rarely used in language classrooms. In Malaysia, Debate is more commonly carried out as a co-curricular activity where each year at the district level, each school would send three representatives to participate in its Annual Debate Competition (Othman, 2005; Othman et al., 2013). Hence, it is an exclusive activity often open to those who are proficient in the language. Occasionally, a professional development course on how to adjudicate Debate is carried out, but teachers seldom use Debate as a pedagogy tool in their language or content classroom.

\subsection{Philosophical Inquiry Classroom Discussion}

Philosophy Inquiry discussion is the pedagogy used in the children thinking program, Philosophy for Children (P4C), created by Mathew Lipman in the1960s (Lipman, 1980). For this program, Lipman created his own text of stories about children who were inquisitive and constantly deliberate on matters which puzzled them. The texts created were dialogic for the characters would think aloud their thoughts or what is termed as "Inner dialogues" (Vygotsky, 1986). By reading these text, students internalized the inquisitive nature of the characters. Lipman also incorporated the Socratic Method in this pedagogy where after reading the text students would pose questions based on the text. In the teacher-led discussion, the teacher will initially lead the discussion where 
students are probed to think critically of opinions expressed by their friends. Thus, with the teacher acting as the facilitator, students will engage in a dialogic discussion and deliberate among themselves. Through Socratic Method, the process of deliberation is internalized and students gradually become reflective and begin to think for themselves. In the process a community of inquiry is created and gradually a student-led discussion will take place. As stated by Lipman (2009) the program P4C "aims to encourage children to develop their own way of thinking by confidently expressing their opinion about the world in a safe environment (p. 166)."

Since its introduction, the Program P4C has been successfully implemented in various countries, including United Kingdom, Australia, New Zealand, Iran, Mexico and South Korea. In Singapore it was selectively carried out among its premier schools such as Raffles. Research on this program has shown that it facilitates students to think and argue well, to be reasonable and to improve students' communicative spoken skills. Students who undergo the Program $\mathrm{P} 4 \mathrm{C}$ are said to acquire four attributes of becoming creative, critical, caring and collaborative (Sutclliffe, 2015).

In Malaysia, the Philosophical Inquiry pedagogy was introduced in 2002 via the introduction of the children thinking program, P4C program, by Rosnani Hashim who received first-hand training from Mathew Lipman. The program was named the "Hikmah" Program and in 2006 the Centre for Philosophical Inquiry in Education (CPIE) was set up at the Institute of Education, IIUM to promote the Philosophical Inquiry pedagogy to the Malaysian Education through the Philosophy for Children (P4C) program (Preece \& Juperi, 2014). Several studies related to Philosophical Inquiry were carried out at the primary, secondary and tertiary levels by its members. Among the studies were Hashim (2003, 2009), Othman (2005), Juperi (2010), Abdullah (2011) and Preece (2012). The results showed positive improvement in the subjects' cognitive and English language skills. Presently, the program has been carried out in private schools as a stand-alone program.

\section{Method}

The present study used a quantitative method, a pretest-post-test experimental design, to determine the effect of two programs on ESL learners who were randomly divided into two groups and given two different types of treatments: Group A: Debate instruction; and, Group B: instruction of Philosophy Inquiry classroom discussion.

\subsection{Participants and Data Collection Procedures}

The study focused on 32 ESL undergraduate students attending Oral and Aural course at University Putra Malaysia. The researchers used Fish Bowl method to divide the students into two equal groups. At the beginning of the semester, a pre-test questionnaire was given to the participants. Before that, the researchers obtained consent from the class lecturer and students to perform this research. Clarification on the items of the questionnaire was also given to the participants. Throughout the semester, the participants took part in various tasks given according to their groups. During the 8th week of the semester, a post-test was conducted to collect the data on their WTC after giving the treatment accordingly.

\subsection{Treatment}

There were two kinds of treatments in the study. First, one group (A) had a Debate instruction as a treatment. During the introduction the instructor explained about Debate, its structure, format, roles of each speaker, structure of an argument and a rebuttal. Subsequently, students carried out a mock Debate and at the end of it the instructor gave an evaluation of their delivery and argument. For subsequent lesson, students debated on topics related to the course outline. Topics were given before the actual class for students to do research on the topics. For each class, students were given half an hour to brainstorm and discuss their points. Throughout the lesson students came to the front to deliver their arguments.

Second treatment was a Philosophy Inquiry discussion for group B which during the introduction the instructor showed the studets how to carry the PI discussion. They were seated in a circle and were each given a text. This was read out loud paragraph by paragraph by each student. After reading the text, students raised controversial issues pertaining to the text. This became the agenda of each discussion. The instructor as the facilitator would lead the discussion initially. A student was appointed as the moderator as well. The instructor facilitated the discussion, mentoring the moderator as well. Each week students were given the text beforehand so that they would come prepared.

\subsection{Instruments}

The data were collected using the WTC questionnaire (McCroskey, 1992) to determine the participants' WTC before and after the Debate and PI discussions. This questionnaire consists of three parts: section A, which measures WTC; section B which assesses Communication Apprehension; and section C which measures Communicative Competence. This section comprises of 12 items developed by McCroskey (1992) to assess 
students' Willingness to Communicate in English to strangers, acquaintances and friends in different communicative context. Among the contexts it assessed are public speaking, talking in meetings, group discussions, and interpersonal conversations. For this questionnaire, the respondents needed to choose the percentage of the willingness between 0 (totally not willing to) and 100 (totally willing to).

\subsection{Data Analysis}

The pre- and post-test data from both Debate and Inquiry classroom discussion were analyzed using IBM SPSS version 20 to obtain descriptive statistics as well as to conduct t-test to compare between and within groups.

\section{Results}

\subsection{Results on Willingness to Communicate (WTC)}

\section{(i) Pre-test Results for the Two Groups}

There were two equal sized groups in this study, the Debate group (A) and Philosophical Inquiry discussion group (B). An independent t-test was used to determine if there was any significant difference between the two groups at the start of the study.

Table 1. Independent samples t-test for the performance of both groups on the pre-test for WTC

\begin{tabular}{lllll}
\hline & Groups & & \\
\hline & Debate & PI Discussion & T & Sig. \\
\hline Pre-Test (WTC) & 52.33 & 51.29 & .676 & .422 \\
\hline
\end{tabular}

Note: $* \mathrm{P}<.05$.

The result (Table 1) shows that there is no significant difference between the two groups on WTC before the treatments.

\section{(ii) Pretest/Posttest Results for the Two Groups}

To answer the first question (Do PI classroom discussion and Debate instructional methods make any differences on ESL learners' WTC scores?) paired t-test was run to test the following hypothesis: Ho: There is no statistically significant difference in means of the pre- and post-tests for each treatment.

Table 2. Paired samples t-test for Debate (Group A) on WTC

\begin{tabular}{lllll}
\hline & Tests & & \\
\hline & Pre-Test & Post-Test & T & Sig. \\
Debate & 52.33 & 61.76 & $6.76^{*}$ & .000 \\
\hline
\end{tabular}

Note: $* \mathrm{P}<.05$.

For Debate, the result (Table 2) shows that there is a statistically mean difference for WTC $(t=6.76, p<0.05)$. Therefore, there is adequate evidence to reject the null hypothesis (Ho) as there is a statistically significant difference in means between the pre- and the post-test.

Table 3. Paired samples t-test for PI discussion (Group B) on WTC

\begin{tabular}{lllll}
\hline & Tests & & \\
\hline & Pre-Test & Post-Test & T & Sig. \\
PI Group & 51.29 & 59.80 & 3.16 & .004 \\
(WTC) & & & & \\
\hline
\end{tabular}

Note: $* \mathrm{P}<.05$. 
Similarly, for PI discussion, the result (Table 3) shows that there is a statistically mean difference for WTC. Hence, there is also adequate evidence to reject the null hypothesis for PI discussion group. Thus, it can be concluded that there is a significant mean difference in the pre- and post-test of WTC in Debate group and PI discussion group.

\section{(iii) Post-test Results for the Two Groups}

This section aims to answer the second question: Is there any significant difference in mean scores between Debate and PI discussion groups? Therefore, an independent test was employed to determine the following hypothesis: Ho: There is no significant difference in mean scores between Debate and PI discussion groups for WTC.

Table 4. Independent samples t-test for the performance of group A and B on the post-test

\begin{tabular}{lllll}
\hline \multicolumn{5}{c}{ Groups } \\
\hline & Group A & Group B & T & Sig. \\
Debate & PI Discussion & & \\
Post-Test & 67.16 & 59.80 & 4.27 & .002 \\
\hline
\end{tabular}

The result of the t-test (Table 4) reveals that there is a statistically significant difference in mean sores between the PI discussion and Debate groups for WTC. This indicates the Debate participants recorded a significant improvement of WTC compared to PI discussion.

\subsection{Results on Self-Perceived Communicative Competence (CC)}

In this section, it is aimed to answer the third research question: Which approach promotes Self-Perceived Communicative Competence (CC) more: PI classroom discussion or Debate?

A pre- and post-test for Communicative Competence was undertaken for the two groups. In order to find which of these two methods promotes more Communicative Competence, the learners' scores on both pre- and post-tests for each group were compared. The following Table shows the results for both methods:

Table 5. Comparison between mean scores of Communicative Competence of both groups

\begin{tabular}{lll}
\hline & Communicative Competence (CC) & \\
\hline Debate & Mean & Differences of Mean \\
Pre-test & & \\
Post-test & 49.22 & 4.39 \\
PI Discussion & 53.61 & \\
Pre-Test & & \\
Post-Test & 49.17 & 2.46 \\
\hline
\end{tabular}

From the table above, it can be seen that the participants in Debate Program showed a higher level of Communicative Competence. There is an increment of 4.39, while in the PI discussion the increment is 2.46. Thus, those in Debate showed more improvement in Self Communicative Competence.

\subsection{Results on Communicative Apprehension (CA)}

This section aims to answer the last research question: Which approach increases Communicative Apprehension (CA) more: PI classroom discussion or Debate? 
Table 6. Comparison between mean scores of Communicative Apprehension (CA) of both groups

\begin{tabular}{lll}
\hline & Communicative Apprehensiveness & \\
\hline PI Discussion & Mean & Differences of Mean \\
\hline Pre-test & 50.34 & \\
Post-test & 52.16 & 1.82 \\
Debate & & \\
Pre-Test & 49.21 & 1.96 \\
Post-Test & 51.17 & \\
\hline
\end{tabular}

Result of the means for both groups, Debate and PI discussion, as presented in Table 6, shows that the mean difference of Communicative Apprehensiveness is slightly higher in Debate group, 1.96, as compared to the difference in means of the PI discussion group, 1.82. Thus, this shows that students in Debate, experienced more apprehensiveness than the PI discussion group.

\section{Discussion}

The results of the study show that both instructional methods improved students' Willingness to Communicate and Self-Communicative Competence. In comparison, Debate was more effective in promoting students' Willingness to Communicate and Self-Communicative Competence. In terms of Communicative Apprehension, participants in both programs experienced it as well. However, Debate triggered apprehensiveness more.

Self-Communicative Competence is the feeling of having confidence to be able to communicate effectively at a particular situation (MacIntyre et al., 1998) which can occur as a result of states of previous successful communication encounter/(s) and having the knowledge and skills to keep the communication going (Weaver, 2010). This might explain why Debate resulted more improvement in Self Communicative Competence and Willingness to Communicate. In Debate, everyone had a role as a Debate speaker and it was mandatory for each speaker to deliver an argument. Thus, they had more opportunity to practice speaking and consequently they improved their communicative skills. As stated by Liu and Littlewood (1997), with more practice of speaking and being engaged in speaking, the students would improve their language, communication skills and confidence. Thus, with more opportunities, they become more confident and more willing to communicate. However, in PI discussion group, interactions were among the participants, the moderator and instructor. Each played an important role to drive the discussion. Moreover, in PI classroom, it was not compulsory for all participants to give their point of view during the discussion. Since not everyone in PI participated in the discussion, the general level of Willingness to Communicate and Self- Communicative Competence was less in PI discussion when compared to Debate.

The level of apprehensiveness was more in Debate than in PI discussion. There are "many of the skills [that] take a year to build, as do the relationships that support rich conversations" (Zwiers \& Crawford, 2011, p. 29). In PI discussion, it is not mandatory for its participants to engage in the discussion, so if students do not have these skills they would abstain from discussion; however, such a choice is not available in Debate as it is compulsory for all speakers to deliver their argument. In Debate, participants may often feel anxious as they have to prepare and deliver their speech one after another and each speaker has a specific role: either to define the key word, to give a point, to rebut or to deliver a summary of their arguments. Furthermore, they have to be mentally prepared to answer impromptu questions probed by members of the opponent.

\section{References}

Abdullah, N. (2011). Philosophy as a tool to enhance critical thinking among Muslim students. In S. Hussein (Ed), Selected readings in Educational Foundations: Ummatic Ramifications (pp. 25-50). Gombak: International Islamic University Malaysia (IIUM).

Bellon, J. (2000). A research based justification for debate across the curriculum. Argumentation and Advocacy, $36(3), 161-173$.

Darby, M. (2007). Debate: A teaching-learning strategy for developing competence in communication and critical thinking. Journal of Dental Hygiene, 81(4), 1-10.

Dörnyei, Z. (2003). Attitudes, orientations, and motivations in language learning: advances theory, research, and applications. Ann Arbor: Blackwell. https://doi.org/10.1111/1467-9922.53221 
Dörnyei, Z. (2005). The psychology of the language learner: Individual differences in second language acquisition. Mahwah, NJ: Lawrence Erlbaum. https://doi.org/10.1177/0261927X05281424

Ericson, J. M., Murphy, J. J., \& Zeuschner, R. B. (2003). The debater's guide (3rd ed.). Illinos: South Illinois University Press.

Garrett, M., Schoener, L., \& Hood, L. (1996). A teaching strategy to improve verbal communication and critical-thinking skills. Nurse Education, 21(4), 37-40. https://doi.org/10.1097/00006223-199607000-00015

Gervey, R. O. (2009). Debate in the classroom: An evaluation of critical thinking teaching technique within a rehabilitation counseling course. Rehabilitation Education, 23(1), 61-74. https://doi.org/10.1891/088970109805059209

Hall, D. (2011). Debate: Innovative teaching to enhance critical thinking and communicative skills in healthcare professionals. The Internet Journal of Allied Sciences and Practice, 9(3), 1-8.

Hashim, R. (2003). The teaching of Thinking through the Philosophy for Children Approach in Malaysia. Unpublished Research Report. Gombak: International Islamic University Malaysia (IIUM).

Hashim, R. (2009). Philosophy in the Islamic Tradition: Implication for the Philosophy for Children (P4C) Program. In E. Marsal, T. Dobashi, \& B. Weber (Eds), Children Philosophize Worldwide: Theoretical and Practical Concepts (pp. 655-662). New York: Peter Lang.

Jugdev, K., Markowski, C., \& Mengel, T. (2004). Using the debate as an online classroom. Online Classroom, l(10), 4-6.

Juperi, J. A. (2010). Philosophical inquiry in Islamic education and its effect in the development of questioning skills among secondary school students (Master's Dissertation). International Islamic University Malaysia, Gombak.

Kennedy, R. (2007). In-class debates: Fertile ground for active learning and the cultivation for critical thinking and oral communication skills. International Journal of Teaching and Learning in Higher Education, 19(2), 183-190.

Lipman, M. (1980). Philosophy in the Classroom. Philadelphia: Temple University.

Lipman, M. (2009). A Life Teaching Thinking. Cambridge: Cambridge University Press.

Liu, N. F., \& Littlewood, W. (1997). Why do many students spear reluctant to participate in classroom learning discourse? System, 25(3), 371-384. https://doi.org/10.1016/S0346-251X(97)00029-8

MacIntyre, P. D. (2007). Willingness to communicate in the second Language: Understanding the decision to speak as a volitional process. The Modern Language Journal, 91, 564-576. https://doi.org/10.1111/j.1540-4781.2007.00623.x

MacIntyre, P. D., \& Doucette, J. (2010). Willingness to communicate and action control. System, 38, 161-171. https://doi.org/10.1016/j.system.2009.12.013

MacIntyre, P. D., \& Gardner, R. C. (1994). The subtle effects of language anxiety on cognitive processing in the second language. Language Learning, 44, 283-305. https://doi.org/10.1111/j.1467-1770.1994.tb01103.x

MacIntyre, P. D., Clément, R., Dörnyei, Z., \& Noels, K. A. (1998). Conceptualizing willingness to communicate in a L2: A situational model of L2 confidence and affiliation. Modern Language Journal, 82, 545-562. https://doi.org/10.1111/j.1540-4781.1998.tb05543.x

MacIntyre, P. D., Baker, S. C., Clément, R, \& Conrad, S. (2001). Willingness to communicate, social support, and language-learning orientations of immersion students. Studies in Second Language Acquisition, 23, 369-388. https://doi.org/10.1017/S0272263101003035

MacIntyre, P. D., Baker, S. C., Clément, R., \& Donovan, L. A. (2003). Talking in order to learn: Willingness to communicate and intensive language programs. The Canadian Modern Language Review, 59(4), 589-607. https://doi.org/10.3138/cmlr.59.4.589

Makdisi, G. (1981). Rise of Colleges: Institutions of learning in Islam and the West. Edinburgh: Edinburgh University Press.

McCroskey, J. C., \& Baer, J. E. (1985). Willingness to communicate: The construct and its measurement. Paper presented at the annual convention of the Speech Communication Association, Denver, CO.

McCroskey, J. C., \& Richmond, V. P. (1987). Willingnessto communicate and interpersonal communication. In J. 
C. McCroskey, \& J. A. Daly (Eds.), Personality and interpersonal communication (pp. 129-156). Beverly Hills, CA: Sage.

McCroskey, J. C., \& Richmond, V. P. (1990). Willingness to communicate: A cognitive view. Journal of Behavior and Personality, 5, 19-37.

McCroskey, J. C. (1992). Reliability and validity of the willingness to communicate scale. Communication Quarterly, 40, 16-25. https://doi.org/10.1080/01463379209369817

Moon, J. (2005). Critical thinking. Bristol: Bristol: ESCalte Publication.

Oros, A. (2007). Let's debate: Active learning encourages student participation and critical thinking. Journal of Political Science Education, 3, 293-311. https://doi.org/10.1080/15512160701558273

Othman, M. (2005). Critical thinking and reading skills: A comparative study of the readers response and philosophy for children approaches. (PhD Dissertation). International Islamic University Malaysia (IIUM).

Othman, M., F. Mohamad, \& Amiri, F. (2013). English debate league competition among lower form students: An experiential learning activity. US-China Foreign Language, 11(11), 840-853.

Preece, A. S. (2012). Benefitting Muslim learner's using philosophical inquiry. Presented at the 21st MELTA International Conference, Kuala Lumpur.

Preece, A. S., \& Juperi, A. (2014). Philosophical Inquiry in the Malaysian Educational System - Reality or Fantasy? Analytic Teaching and Philosophical Praxis, 35(1), 26-33.

Skehan, P. (1989). Individual Differences in Second-language Learning. London: Edward Arnold.

Sutcliffe, R. (2015). Philosophical Inquiry: P4C Program: Workshop: International Islamic University Malaysia (IIUM), Gombak, Malaysia.

Swain, M. (1985). Communicative competence: Some roles of comprehensible input and comprehensible output in its development. In S.M. Gass \& E. Voranis (Eds.), Input in second language acquisition. Rowley, M.A.: Newbury House.

Vo, H. X., \& Morris, R. L. (2006). Debate as a tool in teaching economics: Rationale, technique and some evidence. Journal of Education for Business, 81(6), 315-320. https://doi.org/10.3200/JOEB.81.6.315-320

Vygotsky, L. (1986). Thought and language. Cambridge, MA: The MIT Press.

Weaver, C. (2010). Japanese university students' willingness to use English with different interlocutors. Unpublished doctoral dissertation, Philadelphia: Temple University.

Zwiers, J., \& Crawford, M. (2011). Academic conversations: classroom talk that fosters critical thinking and content understanding. Portland, ME: Stenhouse Publishers.

\section{Copyrights}

Copyright for this article is retained by the author(s), with first publication rights granted to the journal.

This is an open-access article distributed under the terms and conditions of the Creative Commons Attribution license (http://creativecommons.org/licenses/by/4.0/). 